\title{
SERVQUAL Gap Analysis of Nepalese Commercial Banks
}

\author{
Makshindra Thapa, $P h D$ \\ Lecturer, Tribhuvan University \\ Visiting Faculty, Nesfield International College \\ Email: tmakshindra@yahoo.com
}

\begin{abstract}
The main objective of this paper is to present empirical findings regarding service quality being offered by Nepalese commercial banks. The SERVQUAL gap analysis has been applied to measure extent of service quality expected and actually perceived by the customers within five dimensions; tangibles, reliability, responsiveness, assurance and empathy. The gap analysis finding is based on responses of 216 bank customers. A questionnaire survey conducted consisting the SERVQUAL instrument with 22 items used for the survey originated by Parasuraman et al. (1988). The result of gap analysis showed that there remarkable service quality gaps in all five dimensions of SERVQUAL. Empathy and assurance have more gaps relative to other dimensions. Independent sample test showed that there is no significant difference between male and female respondent's perceived gaps in service quality of these banks.
\end{abstract}

Keywords: service quality, service quality dimensions, SERVQUAL model, gap analysis, SERVQUAL gap, Nepalese commercial banks

\section{Introduction}

The Nepalese financial sector is composed of banking sector and non-banking sector. After the liberalization effort of 1990s, this sector has seen many drastic changes in terms of opportunities, competition, technology and market. Due to growing number of the firms within the industry from domestic and international investors, the industry now is more sensible towards improvement of service quality. Similarly, achieving customer satisfaction has become one of the key strategic issues among Nepalese bank managers.

There are many management approaches concerning improving level of service quality and customer satisfaction. Service quality is a function of pre-purchase customers, expectation, perceived process quality, and perceived output quality. Parasuraman, Berry, and Zeithaml (1988) defined service quality as the gap between customer's, expectations of service and their perception of the service experience. The SERVQUAL approach is one of the commonly applied tools to manage service quality by analyzing customer expectations and perceptions as well. SERVQUAL has been applied in service and retailing organizations (Parasuraman et al., 1988). Basically, Parasuraman et al. 
(1988) has great contribution in conceptualization of service quality. The original SERVQUAL instrument included 22 items which are grouped into five dimensions: tangibles, reliability, responsiveness, assurance, and empathy.

SERVQUAL represents service quality as the discrepancy between a customer's expectations for a service offering and the customer's perceptions of the service received, requiring respondents to answer questions about their expectations and perceptions (Parasuraman et al., 1988). Later The Gap Model of Service Quality is developed by Parasuraman, Berry, and Zeithaml (1985) to conceptualize the definition of perceived service quality as the gap between what is expected (should-be provided service) and what is perceived (did-provided service).

According to the model the first gap exists between Customer expectation and management perception. The second gap lies between management perception and service quality specification gap. The third gap is in between of service quality specification and service delivery. The fourth gap measures the difference between service delivered and what is externally communicated to customers about the service. The fifth gap which measures the difference between customers' expectations of the service and the actual service they perceived to have received.

This study is focused in determining existing gaps between expected and perceived service qualities offered by Nepalese banks. For this purpose SERVQUAL model with 22 items of service quality measurement and gap analysis originated by Parasuraman et al. (1988) have been used. The study of these service quality gaps gives bank managers to know what customer want; to select appropriate service designs and standards; to deliver to these standards; and to match performance to promises.

\section{Review of Literature}

\section{Service Quality and its Measurement}

Service quality implies with those service attributes which ultimately satisfies customers more and provides more value for their price. It is the ability of an organization and its employee to deliver services in excellent fashion producing low customer complaints and dissatisfaction. Contemporary global business has been dominated by service industry. There is intense competition in the service industry where quality matters more. Customers can freely move from one provider to the other without too much of inconveniences. As a result, service quality becomes critical in maintaining the competitive edge, resulting in service quality becoming one of the most explored areas (Paul, Mittal, \& Srivastav, 2016). 
Service quality is based on judgment made by the service receiver. Service quality is the customer's perception of the degree to which the service rendered meets their expectations (Parasuraman et al., 1988). The approximation of service quality comes from the comparison of actual service performance with the expected service performance; essentially, it is the perceived quality (Parasuraman et al., 1985). Zeithaml (1987) defines perceived quality as the customer's judgment on an organization's overall excellence and high quality. Similarly, Parasuraman et al. (1988) have stated service quality gap as the outcome of comparison between expectations and perceptions of performance.

Measurement of service quality involves in examining the extent to which the service level delivered matches customer expectations and this requires the service provider to deliver quality service on a consistent basis to enhance customer trust. Parasuraman et al. (1985) states that service quality evaluations are not based solely on the outcome, but also include the process of service delivery. Measurement of service quality is more subjective nature hence it is difficult to measure. However, there has been measurement models developed to measure service quality in literature.

\section{SERVQUAL based Gap Analysis}

SERVQUAL is the most applied tools in measuring and analyzing service quality. Paul et al. (2016) have stated that SERVQUAL is a generally accepted model for measuring the quality of various businesses proving services. SERVQUAL is based on the disconfirmation paradigm, which compares the customer service expectations and service perceptions to evaluate perceived service quality (Boshoff et al., 2014). It is very effective in measuring customer expectations in different aspects or stages of service processes and actually provided services thus existing gaps between what the customers want and what the firms has served.

Grönroos (1987) developed the first service quality model that measured perceived service quality based on the test of qualitative methods. Currently, there are two main measurement scales of service quality; SERVPERF and SERVQUAL models. In the view of Cronin and Taylor (1992) SERVPERF is a performance-based scale. However SERVQUAL is most used model to measure service quality. In addition, the service quality gap model was developed by Parasuraman et al. (1985). The original model consists of ten dimensions that were later refined to five dimensions for the SERVQUAL model (Parasuraman et al., 1988). The gap model has been helpful in analyze and improve service quality in two ways. The first implication is to reveal gaps exist between customer expectation and the actual services provided at different stages of service 
delivery and the second is to close the identified gap so as to improve the customer service.

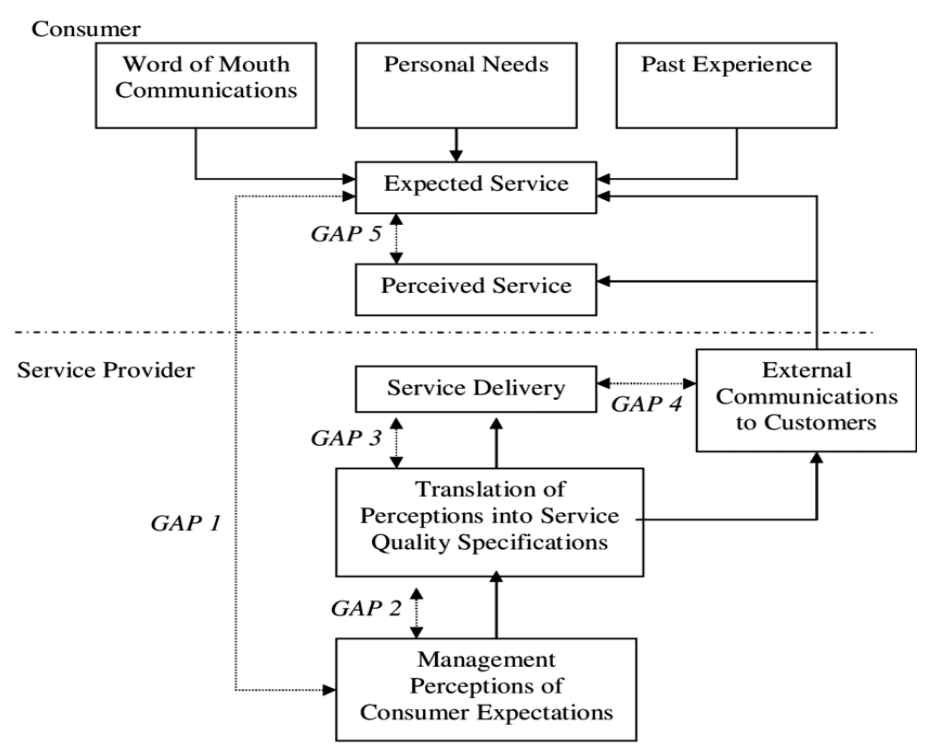

Figure 1. Service quality gap model

Source: Parasuraman et al. (1985)

The Gap model presented by Parasuraman et al. (1985) describes five different gaps existing between expectation and perceived quality by the customers. These gaps are; the knowledge gap, the standards gap, the delivery gap, the communication gap and the customer gap.

Gap 1: This gap represents to the gap between expectations of the customers and perceptions of management about various attributes of service quality. Zeithaml, Parasuraman, and Malhotra (2002) have stated that this gap arise when management have not correctly interpreted the customer expectations and they are trying to meet incorrect consumer needs. However, this gap can be closed through comprehensive market research. It is the gap between understanding of the service provider and service receiver.

Gap 2: This gap is related to misrepresentation of customer expectation by management reflected in service design. Zeithaml et al. (2002) have explained the gap the difference between management perceptions of customer expectations and service quality 
specifications. This gap arises due to management's wrong translation of the service design, service policy and employee guidelines.

Gap 3: This is the difference between service quality specifications and the service actually delivered to customers. Furthermore, this gap is a result of employees' lack of training in fulfilling service specifications, resulting in an ill-equipped workforce to deliver the promised service (Zeithaml et al., 2002). This is actually the delivery gap due to delivering wrong service attributes than of the specifications made during the process of designing services.

Gap 4: This gap is also known as the communication gap. It measures the difference between service delivered and what is externally communicated to customers about the service. In most of the cases it is caused due to service providers' over promising through advertising and communication thereby raising customer expectations. This leaves customers frustrated and might seek alternative service provider for the service (Zeithaml et al., 2002). So, ambitious promotional efforts lead to over expectations of the customers causing dissatisfaction.

Gap 5: this is customer based gap which measures the difference between customers' expectations of the service and the actual service they perceived to have received. As customer expectations are based on available resources and these are influenced by cultural background, family lifestyle, personality, demographics, advertising, experience with similar products and information available online. The customer gap is the most important gap; it can be closed by understanding customer needs, and knowing customer expectations (Zeithaml et al., 2002). It has been termed as the customer gap. This gap is commonly measured by the SERVQUAL model.

Customer satisfaction and service quality are interrelated. Banking institutions can enhance their service quality by analyzing all mentioned service gaps. This model of gap analysis is very useful to explore critical and key service variables that affect service quality. Moreover the analysis can assist decision makers in generating possible ways to close or narrow those gaps to ensure customer satisfaction with the service delivered.

\section{Research Methods}

This study aims to report customer responses about service quality they are being provided by Nepalese commercial banks. The service gap between customer expected and perceived quality in five SERVQUAL dimensions are focal issues of this study. Similarly examining service quality gap differences between male and female customers is the other issues to fulfill these objectives, This study applies the descriptive research design. To reveal customer opinions about their expectations about various dimensions 
of banking service quality and they actually have perceived from services, questionnaire survey have been conducted by the researcher. A standardized questionnaire has been administered using the modified form of SERVQUAL model as suggested by Parasuraman et al. (1985).

\section{Questionnaire Survey Administration}

The questionnaire consisted of 22 service quality related measures divided into five SERVQUAL dimensions as;

- Tangibles Measures: Under this dimension five items of service quality were included- Visually appealing Infrastructures, Hi-tech and up-to-date equipment, physical facilities, wide networks, and visually appealing statements and broachers.

- Reliability Measures: This dimension also consists five items as; Timely services as per promise, sincere interest in solving customer problems, performing service right the first time, error free record system, and operating hours.

- Responsiveness Measures: There are four items applied under this dimensions. They are; traits of bank staffs, service delivery time of staff, staff's willing to handling problems, and staffs attitude to respond to customer requests.

- Assurance Measures: Four measures are included in assurance dimension as; staff behavior, confidence of customers, nature of staffs, and knowledge of staffs.

- Empathy Measures: Included items within this dimension are; individual attention to customers, convenient operating hours, personal attention to customers, and staffs understanding specific needs of customers.

The items in the questionnaire were measured on a 5-point Likert scale that ranging from $1=$ "Very Unsatisfied" to 5 = "Very Satisfied".

The target population were bank customers of largest commercial banks of Nepal including; Nepal Bank Limited, Rastriya Banijya Bank Limited, Nepal Investment Bank, and Citizens International Bank Limited. Sample frame consisted to those who receive bank service in the form of loan seekers and depositors. The personal administered survey consisted, altogether 250 questionnaires distributed to the equally to the bank customers randomly selected in convenience basis within the head office and branches inside of Kathmandu valley. Out of distributed questionnaires, 216 usable responses were considered for the analysis. The response rate was $86 \%$. The data collection procedure was done during three months period of January- March 2020. 


\section{Reliability of the Instruments}

Reliability test is a judgment of the degree of stability and consistency between multiple measurements of a variable. The calculated Cronbach's alpha for 22 items of measures within 5 dimensions is .798. The result has suggested that the service quality dimensions and their independent measures pose quality of stability and consistency as the computed value of alpha is the commonly accepted measurement technique with a generally agreed lower limit of 0.7 .

\section{Results and Discussions}

Data analysis consists of two basic objectives. The first one is to describe status of service quality as perceived by the customers for all five SERVQUAL dimensions and revealing gap between customer expected quality and actually they have perceived. The second objective aims in examining the possible differences of male and female customers on expectation and perception of the quality. The computation of gap has done by subtracting customer perceived quality from their expected. Table 1 depicts the descriptive analysis of five dimensions with means and standard deviations.

Table 1

Descriptive Statistics of the Study Variables

\begin{tabular}{lllllll}
\hline \multirow{2}{*}{$\begin{array}{l}\text { SERVQUAL } \\
\text { Dimensions }\end{array}$} & $\mathrm{N}$ & \multicolumn{3}{c}{ Customer Expected } & \multicolumn{2}{c}{ Customer Perceived } \\
\cline { 2 - 7 } & Valid & Missing & Mean & $\begin{array}{l}\text { Std. } \\
\text { Deviation }\end{array}$ & Mean & $\begin{array}{l}\text { Std. } \\
\text { Deviation }\end{array}$ \\
\hline Tangibles & 216 & 0 & 3.4896 & 0.67699 & 3.0738 & 0.66145 \\
Reliability & 216 & 0 & 3.5213 & 0.55933 & 3.2625 & 0.60165 \\
Responsiveness & 216 & 0 & 3.6447 & 0.61063 & 3.2965 & 0.60392 \\
Assurance & 216 & 0 & 3.6701 & 0.57692 & 2.8456 & 0.51788 \\
Empathy & 216 & 0 & 3.775 & 0.61024 & 2.6912 & 0.54557 \\
\hline
\end{tabular}

The results reflect remarkably divergent customer expectations and perceptions for five SRVQUAL dimensions. The customers have expected better that average service from their banks for all five dimensions as mean value of these variables almost exceed 3.5. Moreover these customers have shown more expectations for empathy, assurance, responsiveness, and then to tangibles respectively. The result from actual customer received and perceived quality seems to more differ than of the expectations. Both empathy and assurance mean score are below that 3 indicating near customer dissatisfactions.

Table 2 presents the gap analysis resulted from the gap between customers' perceived quality and expected quality of five SERVQUAL dimensions of the study. 
Table 2

Costumer Expected and Perceived Service Quality with Gap

\begin{tabular}{llll}
\hline SERVQUAL & $\begin{array}{l}\text { Mean Value for } \\
\text { Average of Perceived } \\
\text { Quality }\end{array}$ & $\begin{array}{l}\text { Mean Value for } \\
\text { Average of } \\
\text { Expected Quality }\end{array}$ & $\begin{array}{l}\text { Gap in Quality } \\
\text { (Perceived- } \\
\text { Expected) }\end{array}$ \\
\hline Tangibles & 3.0738 & 3.4896 & -0.4157 \\
Reliability & 3.2625 & 3.5213 & -0.2588 \\
Responsiveness & 3.2965 & 3.6447 & -0.3481 \\
Assurance & 2.8456 & 3.6701 & -0.8245 \\
Empathy & 2.6912 & 3.775 & -1.0838 \\
\hline
\end{tabular}

The gaps in service quality dimensions are differences between perceived quality and expected quality within these dimensions. The positive gaps represent customer satisfaction due to presence of more quality than their expectations whereas negative gaps show deficiency in services leading to customer disappointment. The statistics of Table 2 indicate larger service quality gaps in empathy and assurance dimensions. Relatively tangibles dimensions have moderate gaps. Reliability has lowest negative gap among all five dimensions.

\section{Service Quality Gap as per Customer Gender}

One of the study intentions was to examine service quality gaps within the five dimensions as per customer gender.

Table 3

Gender Wise Descriptive Statistics of the Study Variables

\begin{tabular}{llllll}
\hline SERVQUAL & Gender & $\mathrm{N}$ & Mean & Std. Deviation & Std. Error Mean \\
\hline \multirow{2}{*}{ Gap in Tangibles } & Male & 96 & -0.4068 & 0.27305 & 0.02787 \\
& Female & 120 & -0.4229 & 0.37208 & 0.03397 \\
Gap in Reliability & Male & 96 & -0.2458 & 0.28467 & 0.02905 \\
& Female & 120 & -0.2692 & 0.28219 & 0.02576 \\
Gap in & Male & 96 & -0.3177 & 0.30822 & 0.03146 \\
Responsiveness & Female & 120 & -0.3725 & 0.32024 & 0.02923 \\
\multirow{2}{*}{ Gap in Assurance } & Male & 96 & -0.8344 & 0.52452 & 0.05353 \\
& Female & 120 & -0.8167 & 0.53351 & 0.0487 \\
Gap in Empathy & Male & 96 & -1.1406 & 0.63355 & 0.06466 \\
& Female & 120 & -1.0383 & 0.66726 & 0.06091 \\
\hline
\end{tabular}


50 THE BATUK : A Peer Reviewed Journal of Interdisciplinary Studies $\quad$ Vol. $6 \quad$ Issue No. 2 July 2020 ISSN 2392-4802

Table 3 depicts some descriptive statistics regarding gaps arising due to differences of expectations and perceptions of service quality of the banks by male and female customers. The mean scores for the gap of all five study dimensions have shown mixed results. Male and female have produced largest disagreement in gaps of empathy (mean scores -1.14 and -1.04) dimension. The male respondents have found more service gap of the banks than female respondents. Similarly for responsiveness dimensions female respondents have experienced more gap than of males (mean of gap scores- -.37 and .31). However the service quality gaps within remaining three dimensions tangibles, reliability and assurance are viewed almost similarly by both male and female respondents.

Table 4 displays result of independent samples test that includes Levene's Test for Equality of Variances and t-test for Equality of Means. These results aims to examine whether there are difference between gap perceived by male and female respondents within five SERVQUAL dimensions.

Table 4

Independent Samples Test Result

\begin{tabular}{|c|c|c|c|c|c|c|}
\hline \multirow{2}{*}{ SRVQUAL } & & \multicolumn{2}{|c|}{$\begin{array}{l}\text { Levene's Test for } \\
\text { Equality of Means }\end{array}$} & \multicolumn{3}{|c|}{ t-test for Equality of Means } \\
\hline & & $\mathrm{F}$ & Sig. & $\mathrm{t}$ & df & Sig. (2-tailed) \\
\hline \multirow{2}{*}{$\begin{array}{l}\text { Gap in } \\
\text { Tangibles }\end{array}$} & Equal variances assumed & 5.272 & 0.023 & 0.355 & 214 & 0.723 \\
\hline & $\begin{array}{l}\text { Equal variances not } \\
\text { assumed }\end{array}$ & & & 0.367 & 212.512 & 0.714 \\
\hline \multirow{2}{*}{$\begin{array}{l}\text { Gap in } \\
\text { Reliability }\end{array}$} & Equal variances assumed & 0.126 & 0.723 & 0.602 & 214 & 0.548 \\
\hline & $\begin{array}{l}\text { Equal variances not } \\
\text { assumed }\end{array}$ & & & 0.601 & 202.948 & 0.549 \\
\hline \multirow{2}{*}{$\begin{array}{l}\text { Gap in } \\
\text { Responsiveness }\end{array}$} & Equal variances assumed & 1.988 & 0.16 & 1.27 & 214 & 0.205 \\
\hline & $\begin{array}{l}\text { Equal variances not } \\
\text { assumed }\end{array}$ & & & 1.276 & 206.807 & 0.203 \\
\hline \multirow{2}{*}{$\begin{array}{l}\text { Gap in } \\
\text { Assurance }\end{array}$} & Equal variances assumed & 0 & 0.996 & -0.244 & 214 & 0.807 \\
\hline & $\begin{array}{l}\text { Equal variances not } \\
\text { assumed }\end{array}$ & & & -0.245 & 205.146 & 0.807 \\
\hline \multirow{2}{*}{$\begin{array}{l}\text { Gap in } \\
\text { Empathy }\end{array}$} & Equal variances assumed & 0.072 & 0.788 & -1.145 & 214 & 0.254 \\
\hline & $\begin{array}{l}\text { Equal variances not } \\
\text { assumed }\end{array}$ & & & -1.151 & 207.789 & 0.251 \\
\hline
\end{tabular}

The Levene's test for equality of means produces significant score for tangibles dimension indicating there is a significant variance between male and female gap scores. In the case of remaining four dimensions; reliability, responsiveness, assurance and 
empathy have not significant scores therefore both male and female gap scores are almost equal. However the results of t-test for equality of means of all five dimensions have insignificant p-values (greater than .05) therefore there is no significant difference between male and female mean gap scores. Both of the test statistics suggest that there are no significant differences between male and female mean scores in all five SERVQUAL dimensions used for the study.

\section{Conclusion}

The results have reflect that customers have perceived less service qualities than of their expectations in all five SERVQUAL dimensions; tangibles, reliability, responsiveness, assurance, and empathy. There are negative gap scores of these dimensions. The SERVQUAL gap found to be larger in empathy and assurance dimensions. Similarly remaining three dimensions; tangibles, responsiveness and reliability also produce negative gaps. Nepalese banks do not meet customer expectations nicely and gaps exist within service provided by them. The results of independent samples test that includes Levene's Test for Equality of Variances and t-test for Equality of Means provide evidence that the SERVQUAL gap between customer expected and customer expected are not significantly different between male and female customers. Thus the SERVQUAL gap analysis revealed that the retail banking customers expect better service quality compared to what they are currently receiving from banks. To fulfill such gaps, the banks can identify and analyze gaps within given service processes. A revised service process designs could be helpful to produce positive gaps in service quality dimension leading more customer satisfaction.

\section{References}

Ahmed, M. (2017). Service quality measurement regarding banking sector. International Journal of Business and Social Science, 8(6), 116-127.

Ali, M., \& Raza, S. A. (2017). Service quality perception and customer satisfaction in Islamic banks of Pakistan: the modified SERVQUAL model. Total Quality Management \& Business Excellence, 28(5-6), 559-577.

Arora, A., \& Arora, P. (2015). Service quality dimensions: an empirical investigation of commercial banks in India using SERVQUAL. International Journal of Services and Operations Management, 21(1), 50-72.

Ashraf, E., \& Venugopalan, K. (2018). Service quality and customer satisfaction: A comparison between public and private sector banks in Kerala. International Journal of Research and Analytical Reviews, 5(3), 567-572.

Boshoff, C., \& Plessis, P. J. (2014). Services Marketing: A Contemporary Approach (2nd ed.). Cape Town, South Africa: Juta and Company Ltd. 
Buttle, F. (1996). SERVQUAL: review, critique, research agenda. European Journal of Marketing, 30(1), 8-32.

Cronin, J. J., \& Taylor, S. A. (1992). Measuring service quality: a reexamination and extension. Journal of Marketing, 56(3), 55-68.

Cronin, J. J., \& Taylor, S. A. (1992). Measuring service quality: A re-examination and extension. The Journal of Marketing, 56, 55-67.

Crosby, P. B. (1979). Quality is free: The art of making quality certain. New York: New American Library.

Garvin, D. A. (1983). Quality on the line. Harvard Business Review, 61(5), 64-75.

Gronoos, C. (1984). A service quality model and its marketing implications. European journal of Marketing, 18(4), 36-44.

Gronroos, C. (1978). A service-oriented approach to marketing of services. European Journal of Marketing, 12(8), 588-60.

Gronroos, C. (1983). Strategic management and marketing in the service sector. Cambridge, MA: Marketing Science Institute.

Gronroos, C. (1990). Service management and marketing: Managing the moments of truth in service competition. Lexington, MA: Lexington Books.

Kasper, H., Helsdingen, P., \& Gabbott, M. (2014). Services Marketing Management: A Strategic Perspective (2nd ed.). Hoboken, NJ: John Wiley \& Sons, Inc..

Krudthong, S. (2017). A Service Quality Gap Analysis: A Case Study of a Small-Sized Hotel in Bangkok, Thailand. International Journal of Management and Applied Science, ISSN: 2394-7926, 3(10), 20-24.

Parasuraman, A. P., Berry, L. L., \& Zeithaml, V. A. (1988). SERVQUAL: A multipleitem scale for measuring consumer perceptions of service quality. Journal of Retailing, 64(1), 12-40.

Parasuraman, A. P., Berry, L. L., \& Zeithaml, V. A. (1985). A conceptual model of service quality and its implication for future research. Journal of Marketing, 49, 41-50.

Paul, J., Mittal, A., \& Srivastav, G. (2016). Impact of service quality on customer satisfaction in private and public sector banks. International Journal of Bank Marketing, 34(5), 606-622.

Yarimoglu, E. K., (2014). A review on dimensions of service quality models. Journal of Marketing Management, 2(2), 79-93.

Zeithaml, V. A. (1987). Defining and Relating Price, Perceived Quality, and Perceived Value. Cambridge, MA: Marketing Science Institute.

Zeithaml, V. A., Parasuraman, A., \& Malhotra, A. (2002). Service quality delivery through web sites: a critical review of extant knowledge. Journal of the Academy of Marketing Science, 30(4), 362. 